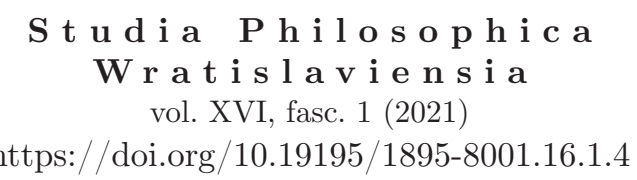

ŁUKASZ HUCULAK

ORCID: 0000-0001-8550-5320

Akademia Sztuk Pięknych im. E. Gepperta we Wrocławiu

\title{
Sztuka i adaptacja. Adoracja, aberracja, abominacja
}

\section{Art and adaptation: Adoration, aberration, abomination}

\begin{abstract}
The text, commenting on The Art Instinct: Beauty, Pleasure, and Human Evolution by Denis Dutton, and the premises contained in it that aesthetic preferences derive from individual and social adaptation mechanisms, will attempt to consider the aspect of the usefulness of art less emphasised by Denis Dutton as a tool for developing and deepening individual perceptual competences. The effective functioning of the nervous system, including efficient handling of individual senses (i.e. the degree of sensitivity to stimuli) and the ability to critically analyse them, provides organisms not only with spatial orientation, but also allows them to plan and predict potential cause-effect sequences.
\end{abstract}

Keywords: evolution, adaptation, evolutionary aesthetics, aesthetics, post-humanism, art, perception, bio-art, sci-art

\section{I}

Dla jednych spłycenie i redukcjonizm, dla innych myśl świeża i odważna. Trop wart zbadania, nawet jeśli ślady prowadzą wprost do wielbicieli kalendarzowych landszaftów. Kogo porywa jeleń na rykowisku — ręka do góry. Czarny kwadrat się nie podoba? To naturalne. Nie dajmy się nabrać na postkonceptualne bzdury. Odrzućmy sofizmaty krytyków, dworujmy z ekscesów z awangardy. 
Uzbrojona w brodę Darwina estetyczna teoria Denisa Duttona ${ }^{1}$ na pierwszy rzut oka intryguje błyskotliwym wyjaśnieniem zawiłych meandrów ludzkich upodobań solidnymi mechanizmami doboru naturalnego. Pociaga potencjałem obiektywizacji „sztuki”, która dla wielu wciąż funkcjonuje jako wzniosła egzemplifikacja subiektywizmu. Szybko ujawniają się jednak pewne niedoskonałości. Tu i ówdzie nobliwa broda okazuje się nierówno przystrzyżona lub niedbale rozczesana. Mimo pewnych deklaracji, niepokoi groźba uśrednienia czegoś ufundowanego na wyjątkowości. Odstręcza spłaszczenie hierarchii zjawisk artystycznych, konsekwentny funkcjonalizm zmierzający, jeśli nie do „ostatecznego”, to choć statystycznie „uśrednionego wyjaśnienia" jednego z najsilniej umocnionych bastionów humanistyki. W zamian estetyka ewolucyjna oferuje demontaż konstruktywistycznych zasieków, za którymi skryła się nowoczesna kultura. Teoria Duttona rozmywa granice sztucznego i naturalnego, dziś już zdecydowanie użyteczne tylko tam, gdzie zamiast odkrywać, chcemy segregować. Z drugiej jednak strony, grzeszy ignorancją wobec tych zjawisk w sztuce, które istotnie płynność tych granic eksplorują. Zrywając sztuce woal ekscesu, czegoś ekskluzywnego w swej nieoczywistości i nienormatywności, Dutton zarazem chciałby, aby pozostała ona manifestacją ludzkiej wirtuozerii. Choć wydawać się może, że istotą tej książki jest krytyczny namysł nad kruchością kulturowej „aury sztuki”, to „piękno i zachwyt” w podtytule (a dodatkowo — okładka polskiego wydania) potwierdzają górnolotny stosunek autora do klasycznych definicji. Brzmi to dziwnie, ale, chcąc być autorem teorii odważnej i redefiniującej, jest Dutton zarazem konserwatorem przykurzonych bibelotów. Jego koncepcja szczególnie pociągać może krytyków artystycznego i naukowego relatywizmu, tęskniących za silną dominantą w świecie paradygmatów. I to chyba zawód największy: składając wspaniałomyślne obietnice, Dutton próbuje nakłonić nas do powrotu w głąb XIX wieku. Oferując wycieczkę do plejstocenu, zabiera nas ledwie za najbliższy róg.

Wydaje się, że sztuka dojrzała do porzucenia imperatywu „bezinteresowności” już w drugiej połowie XX wieku. Dziś z pasją buduje rozmaite społeczno-naukowe alianse, korzystając jednocześnie ze swoistego immunitetu „badań podstawowych”. Powab teorii Duttona bierze się z obietnicy skuteczności, którą oferuje sztuce, przekształcając ją z marginalnego względem innych potrzeb egzystencjalnych zjawiska w metanarzędzie, którego umiejętne stosowanie efektywnie wpływa na zaspokojenie pozostałych potrzeb. Autor aktualizuje jednak ten rejestr, ograniczając jego zasięg właściwie do uwagi potencjalnej partnerki czy partnera. Każe sztuce kierować się instynktem przetrwania, artyście zaś poleca śledzić wybory odbiorcy. Promuje klasyczne kategorie, ufając uśrednionym w oparciu o dane ilościowe powszechnym preferencjom. Gładko przemknąwszy ponad ambicjami awangardy, pewnie ląduje w folklorze. Kosztem szerokiej popularyzacji fetyszyzuje socjologiczno-artystyczny eksperyment Aleksandra Melamida i Vitalija Komara, którego wyniki trudno uznać za radykalnie odkrywcze w którejkolwiek z tych dziedzin. Projekt Rosjan potwierdził raczej obiegowe domysły, rangę zyskując dzięki zainteresowaniu socjologów, którzy $\mathrm{w}$ groteskowych pejzażach the most wanted dostrzegli materiał dla pogłębionych analiz. W gruncie rzeczy jednak podobne dane dostępne były od zawsze w postaci

1 D. Dutton, Instynkt sztuki. Piękno, zachwyt i ewolucja człowieka, tłum. J. Luty, Kraków 2020. 
fototapet, pocztówek i kalendarzy. Co znajdziemy w mieszczańskiej jadalni? Wisi tam ułomek tego, czego brak nam na co dzień: wspomnienie niedzielnych spacerów, harcerskiej przygody, chwil wolnych od pracy, widok przedindustrialnej przeszłości - leśny zagajnik. Domniemany spadek po plejstoceńskich przodkach równie dobrze mógłby świadczyć o tym, że tęsknimy za wakacjami. Niezależnie od tego, czy kojący widok podmiejskiej przyrody to głęboko zapisany w naszej podświadomości model optymalnego obozowiska troglodytów, czy tylko wspomnienie wakacyjnej wyprawy z dzieciństwa, na którym żerują produkty kapitalistycznej globalizacji (jak chciałby Arthur C. Danto), wizja ta wydaje się mało kontrowersyjna. Prawdziwie interesujące byłoby znalezienie klucza dla wcale nierzadkiej dewiacji, którą kierują się wielbiciele surowych, skalistych turni, groźnych przepaści, wzburzonych oceanów. Jedną z najpopularniejszych europejskich destynacji mieszkańców zasobnych krajów arabskich są alpejskie lodowce Szwajcarii i Austrii, w gruncie rzeczy — pejzaż nieco biegunowy, nie aż tak przyjazny. Dlaczego wraz z wykształconymi akademikami i wcale licznymi amatorami estetyki „postapo” pogardzaja oni wywołujacym dobre samopoczucie naszych plejstoceńskich przodków krajobrazem sawanny? Dlaczego pośród tych, którzy będą woleć choćby iluzoryczne bezpieczeństwo, zawsze znajdzie się kilku, którzy chętniej wybiorą ryzyko i niepewność? Jest kilka teorii, w których szukać można wyjaśnień, od romantycznej teorii wzniosłości Edmonda Burke'a, po terror menagement theory Ernsta Beckera ${ }^{2}$. A może zwykły imperatyw poznawczy, obietnica doświadczenia czegoś intrygującego, niejednoznacznego, być może groźnego, ale zarazem nowego, poszerzającego świadomość, wiedzę bądź inne, symboliczne lub materialne zasoby?

Jak podkreśla Jerzy Luty w tekście Estetyka ewolucyjna: sztuka jako adaptacja $w$ ujęciu międzykulturowym ${ }^{3}$, różnice kulturowe z perspektywy poszukiwań metaprzyczyny zjawisk o charakterze estetycznym maja znaczenie drugorzędne. Nie można ich jednak pomijać całkiem, jako potencjalnej emanacji, swoistej projekcji ewolucyjnych źródeł. Zdecydowane twierdzenie ewolucjonistów: sztuka jest cechą wrodzoną, może wydać się wątpliwe jako kontaminacja kategorii z dwóch odległych porządków - „odwiecznego" procesu genetycznego i kulturowego epizodu o krótkim stażu. Słusznie podważając radykalny determinizm kulturowy, Dutton nie odświeża stosownie słownika, powołując się nieustannie na powszechną zdolność „dzieł sztuki” do wywoływania emocji, a szczególnie: sprawiania przyjemności. Emocje wywołuja jednak rozmaite reprezentacje, a często także zjawiska naturalne, status „dzieła sztuki” nie zawsze gwarantuje silne doznania. Źródła i cele praktyk artystycznych natomiast, przy pewnych cechach wspólnych, są jednak zmienne tak geograficznie, jak i historycznie, zwłaszcza w ujęciu tak szerokim i unikajaccym wartościowania, jak chciałby tego Dutton. Wybrzmiewa to nawet w Instynkcie sztuki: o ile praktyce artystycznej i doświadczeniu estetycznemu można przypisać powszechność, to, co ludzie rozumieją pod pojęciem ,sztuki”, różni się niekiedy radykalnie, tak jak różnią nas niekiedy pożądane źródła przyjemno-

\footnotetext{
2 E. Becker, Zaprzeczanie śmierci, tłum. A. Trąbka, Kraków 2015.

3 J. Luty, Estetyka ewolucyjna: sztuka jako adaptacja w ujęciu międzykulturowym, „Estetyka i Krytyka" 21 (2011), s. 101-114.
} 
ści. Wartości te daje się stopniować, co zauważa sam Dutton, analizując pojęcie rzemiosła lub kategorie kopii i fałszerstwa. Dość swobodnie jednak na zmianę to ogranicza badane zjawisko, wykluczając z niego ,statystyczne” dewiacje (awangarda), to znów poszerza o praktyki wykraczające poza produkowanie wizualnych i akustycznych reprezentacji rzeczywistości i stanów duchowych. Czy możemy być pewni, że presja kulturowa, choć radykalnie młodsza niż plejstoceńskie instynkty, nie moderuje dziś wyborów estetycznych, wraz z fizjologią i genetyką wpływając na nasze preferencje kulturowymi kompetencjami oraz społecznym konwenansem?

Jakkolwiek rozmaite instynkty są dość powszechne, ich ekspresja nie w każdym środowisku znajduje warunki dla równie dynamicznego rozwoju. Gdyby było inaczej, zamiast estetycznych rezerwatów mielibyśmy artystyczne plantacje. Sztuka wcale nie jest zjawiskiem powszechnym, w miarę powszechna jest autoekspresja i zdobnictwo. Sztuka zaś jest pewnym ekscesem, służącym bardziej celom poznawczym (i w tym sensie adaptacyjnym), niż zaspokojeniu doraźnych instynktów. Podobnie jak estetyka, jest czymś innym niż powszechniki, do których odwołuje się Dutton, przyjmując za przesłankę do uogólnienia wspólnotę zmysłów, środków i metod. Pozbawioną analiz formalnych czy interpretacyjnych dwuznaczności tradycyjną ornamentykę, geometryczne kształty i rytmiczne wzory, równie wiele łączy, co i dzieli z artefaktami zapośredniczonymi skomplikowanym programem, ikonograficznymi sporami i kompozycyjnymi rozważaniami. Podobne kulturowe różnice ujawnia także dziedzina, którą uprawia sam Dutton: nauka, mając określone ramy teoretyczne i metodologiczne, jest czymś innym niż magia czy szamanizm, za pomocą których stosunek do rzeczywistości, na swój sposób skutecznie, wyraża wiele społeczności. Sądzę więc, że tytułowy „instynkt sztuki”, należałoby traktować równie umownie jak hipotetyczny ,instynkt nauki”, którym nasza wrodzona dyspozycja poznawcza posługuje się od momentu zdefiniowania zasad dowodzenia. Historyczne pojmowanie sztuki wymagałoby może przeanalizowania refleksji Duttona przez pryzmat antropologicznych spostrzeżeń Hansa Beltinga czy Davida Freedberga. To, że tworzenie dwu- lub trójwymiarowych obiektów o wysokim kapitale estetycznym lub symbolicznym jest cechą tak powszechną, jak przetwarzanie pożywienia, nie oznacza, że wszyscy ludzie koncentrują wysiłek na poszukiwaniu specyficznych wrażeń, nie zaś na doraźnym zaspokojeniu potrzeb energetycznych. Czy Dutton nie gubi w swej generalizacji różnicy pomiędzy przygodnym schronieniem a architekturą manifestującą skomplikowane kulturowe treści, zorientowaną na przyciągnięcie uwagi i wywołanie szeregu nieoczywistych kontekstów i pozaegzystencjalnych sensów?

Obszerny rejestr przytoczonych przez niego cluster criteria, towarzyszacych obcowaniu z dziełami sztuki niezależnie od historycznych czy geograficznych ograniczeń, zakreśla pozornie szeroki obszar refleksji estetycznej ${ }^{4}$ : bezpośrednia (niepraktyczna) przyjemność (direct pleasure), biegłość i wirtuozeria (skill and virtuosity), styl (style), nowatorstwo i kreatywność (novelty and creativity), krytyka (criticism), przedstawianie (naśladownictwo) (representation, imitation), szczególne miejsce (special focus), wyrażanie indywidualności (expressive individuality), nasycenie emocjo-

4 D. Dutton, Instynkt sztuki, s. 100. 
nalne (emotional saturation), wyzwanie intelektualne (intellectual challenge), tradycje i instytucje sztuki (art traditions and institutions) i wyobraźnia (imaginative experience). Pomijając jednak różnice w stopniu ścisłości i powszechności owych kryteriów, wydaje się, że wiele z nich łatwo można wyprowadzić z pozostałych (na przykład wirtuozerię ze stylu, kreatywność z wyobraźni). Szczególnie dwa z wymienionych aspektów wystarczyłyby, aby wyróżnić pozostałe oraz zdefiniować doświadczenie estetyczne. To nasycenie emocjonalne oraz wyzwanie intelektualne: sensualna i niezapośredniczona perswazyjność (której brak choćby naukowym opisom) i nieoczywista perspektywa intelektualna (której brak w rzemiośle, folklorze czy propagandzie). Sztuka powinna rzucać przekonujące wyzwanie naszym potocznym sądom i standardowym wyobrażeniom. Wskazując mielizny dotychczasowych ,stylów myślowych" (Ludwik Fleck) i ,sensualizujacc" paradygmaty potencjalne, przyczyni się do przetrwania gatunku skuteczniej, niż dekorując ślubne skrzynie posagowe.

\section{II}

Rozważanie różnic pomiędzy „sztuką” i rzemiosłem wydaje się jedną z najsłabszych stron refleksji Duttona. Wyróżników artyzmu doszukuje się w nieprzewidywalności procesów artystycznych, nie unikając banalnych porównań i trudnych do zrozumienia generalizacji. Powołując się na Robina George'a Collingwooda, Dutton dowodzi: „płacimy rzemieślnikom za pomalowanie domów lub naprawianie zegarów, ponieważ nie posiadamy ich umiejętności. W odniesieniu do umiejętności jako narzędzi służących do powstania ustalonego z góry efektu artyści i osoby kreatywne - mówiąc ściśle nigdy nie wiedzą, co tworzą" "5. Dowodzi tego garść nieznaczących refleksji o naturze postrzegania i mechanizmach ekspresji, spisanych w traktatach Leonarda, Dziennikach Delacroix, Teorii widzenia Strzemińskiego i niezliczonej liczbie artystycznych manifestów i teoretycznych traktatów, w których zwłaszcza artyści dwudziestowieczni nie tylko naświetlają swoje intencje, ale też wyciagają wartościowe wnioski poznawcze. Rzecz jasna, nie mają one tej doniosłości co O powstawaniu gatunków, przynoszą jednak pewne wskazówki, pomagające poczacć coś z tym, co tworzą artyści: Świat bezprzedmiotowy Malewicza, Punkt, linia a płaszczyzna Kandynskiego, Nowe formy w malarstwie Witkiewicza, itp. Jak więc rozumieć stanowcze zapewnienie Duttona: „Mozart nie komponował swojej muzyki, zanim ją skomponował"? ${ }^{6}$ Za każdym razem improwizował, rzetelnie oczyszczając umysł z poprzedniej improwizacji, zanim przystąpił do kolejnej? Proces artystyczny, nawet jeśli jest żywiołowym action painting, opiera się na sprzężeniach zwrotnych, jak każdy inny mechanizm tworzenia, budowania, uczenia. Jest wynikiem nieustannych korekt, wyciągania wniosków z popełnionych błędów, doprecyzowywania metod i doskonalenia procesu. Wieńczy go nie omdlenie, ale najczęściej świadoma ocena tego, czy realizacja jest zgodna z oczekiwaniami. Dynamiczny przebieg samego aktu nie świadczy o somnambulicznym zamroczeniu, ale o dogłębnym zrozumieniu i perfekcyjnej koordynacji wszystkich organów: inte-

\footnotetext{
5 Ibidem, s. 376.

6 Ibidem, s. 377.
} 
lektu, zmysłów i kończyn. Jeśli chcielibyśmy mówić o natchnieniu i geniuszu w perspektywie fizjologicznej, należałoby zapewne obok romantycznych intuicji wykorzystać wyniki z obszaru neuronauk oraz dynamiki chemicznej układu nerwowego. A tym, co istotnie różni sztukę od rzemiosła, nie jest sam proces, ale intencje: odkrycie nowej perspektywy, wywołanie nowego zjawiska, wrażenia bądź tropu interpretacyjnego, zamiast potwierdzenia bądź rozpowszechnienia istniejącego już paradygmatu, stylu czy konwencji. Zgadzając się zasadniczo, że „,budulcem rzemiosła są przepisy, instrukcja, formuła oraz rutyna”, sztuka zaś „podlega deformacjom i jest niezmiennie otwarta na zmiany i niespodziewane zwroty akcji”, zachować należy pewną ostrożność: przewidywalność kanonów akademizmu, rutyna dywizjonizmu, neoplastycyzmu, hiperrealizmu, a zwłaszcza Romana Opałki, nie odbierają tym dziełom wizualnej i intelektualnej odkrywczości. Czy nie jest ryzykowne powołanie się na permanentną zmienność w celu uzasadnienia zapisanej w genach „odwiecznej” niezmienności? „Zmiana pojedynczego słowa lub fragmentu tekstu, inne pociągnięcie pędzlem, mogą zmienić a nawet totalnie odwrócić nie tylko przesłanie dzieła, ale także cel artysty"'. Dodajmy: mogą tė̇ cel pierwotny doprecyzować, uściślić i podkreślić, jak się dzieje zazwyczaj. Dzieło sztuki często odnosi się do bardzo konkretnych problemów, choć środkami innymi niż najpowszechniej stosowany do komunikacji język werbalny. Kolejne „pociągnięcia pędzla” stanowią częściej poszukiwanie optymalnego efektu niż szarżę na oślep. Umiarkowana świadomość natury procesów artystycznych i dystansowanie się do ekscesów moderny, której historia usiana jest ambitnymi teoriami artystycznymi, podważa nieco aspiracje, których dopatrywać chcielibyśmy się w teorii Duttona. Dedykuje ją raczej rękodziełu niż działalności artystycznej w kształcie, jaki dominuje obecnie w obiegu wystawienniczym. Aby Instynkt sztuki był czymś więcej niż efektowną popularyzacją psychologii ewolucyjnej, należałoby dokonać pewnej hierarchizacji zjawisk o charakterze estetycznym, być może osobno analizować praktyki wykorzystujące manualną sprawność i pomysłowość człowieka w celu optymalizacji przestrzeni (rzemiosło), osobno zaś, przez pryzmat psychologii poznawczej, wszelkie praktyki estetyczne o charakterze badawczym, sensualne i konceptualne eksperymenty poszerzające naszą wiedzę o naturze świata zewnętrznego i działaniu mechanizmów społecznych oraz systemu nerwowego i aparatu percepcyjnego człowieka.

Spośród wszystkich ewolucyjnych funkcji działalności artystycznej rozmaite pochodne percepcyjnej autoanalizy, na których znaczna część artystycznego „mainstreamu" koncentruje się od modernizmu, Dutton uznaje za najbardziej akcydentalne. Tymczasem krytyczny namysł nad procesami odbioru i interpretacji bodźców zmysłowych, którego celem jest optymalna korelacja przeżyć twórcy z doznaniami odbiorców, stanowi podstawowe narzędzie analizy w procesie artystycznym. Wydaje się, co więcej, pomocny w określaniu relacji jednostki ze zbiorowością oraz ludzkości z otaczającym ją światem „pozaludzkim”. Z tego powodu faworyzacja przeważających ilościowo w sztukach wizualnych reprezentacji jednoznacznych, łatwo rozpoznawalnych, pasujących do znanych już wzorców nie wydaje się słuszna.

\footnotetext{
7 Ibidem.

8 Ibidem.
} 
Owszem, lubimy to, co znamy, bo wydaje się nam bezpieczne. Identyfikacja zapewnia poczucie stabilności, a stopień zgodności reprezentacji z oryginałem (,,jak żywe") zapewnia stosowną porcję zachwytu nad manualną sprawnością autora. Kryterium „wyjątkowości” kompensuje w tym wypadku kolejna fetyszyzowana przez Duttona jakość: oryginalność rozumiana jako pochodna autorstwa, nie zaś nietrywialnych cech samego przedmiotu. Tymczasem „niepospolitość” powinna polegać na odsłonięciu nowego aspektu zjawiska już znanego lub wskazaniu zjawiska zupełnie nieznanego. To, co prawdziwie interesujące, nie może być w pełni „oswojone": niepewność towarzysząca każdej niestandardowej zmianie w środowisku, jako potencjalne zagrożenie, silnie aktywuje nasz aparat percepcyjny. Wydaje się, że naszą szczególną uwagę — wrażliwość — pobudza coś pośredniego: z jednej strony określonego w stopniu umożliwiającym wyodrębnienie z mnóstwa innych doznań, z drugiej — niejednoznacznego tak, aby uruchomić lawinę procesów poznawczych, łańcuch pozyskiwania, zapisywania, katalogowania i interpretowania danych, który ma prowadzić do określenia potencjalnej użyteczności bądź szkodliwości doznania. Te nowe wrażenia stają się podstawą konstruowania kolejnych modeli, poszerzając zdolność przewidywania potencjalnych zmian. Wydaje się, że z jednej strony swoista nadwrażliwość artysty, z drugiej — jego techniczna umiejętność produkowania sztucznych wyobrażeń, modeli i reprezentacji łączących to, co już znane, z tym, co dopiero możliwe, służy nie tylko zabiciu nudy i zdobyciu uwagi odbiorców, ale również przygotowaniu na niespodziewane zajścia i zjawiska: modelowaniu potencjalnego rozwoju wypadków. Tak ujęty mechanizm sztuki, kompensując pewne ograniczenia nauki, wydaje się nie tylko pociagający, ale też adaptacyjnie użyteczny. Czy poszerzanie i precyzowanie wiedzy o rzeczywistości zwiększa nasze szanse na przetrwanie równie skutecznie, jak kojące widoki sawanny? O ile uznamy, że nauka jako narzędzie wyewoluowała z potrzeby przewidywania i reagowania na zmiany w środowisku, adaptacyjna użyteczność koordynacji bujnej wyobraźni i sprawności manualnej nie powinna budzić kontrowersji. Zastanówmy się raczej, jak to się stało, że porzucając przednaukowy stosunek do rzeczywistości, oddzieliliśmy rzetelnie sztukę od jakże pomocnej nauki, tej pierwszej przypisując jedynie obligatoryjną bezcelowość, czcze emocje i zbytek uśmierzający nudę. Dwudziestowieczna filozofia nauki (Fleck, Kuhn) otwarcie doceniała wagę analizy danych wzrokowych. Tak jak nikt nie zajmuje się użytecznością, uznając, że prędzej czy później wyniki badań podstawowych staną się podstawą rozwiązań służących kontrolowaniu otoczenia oraz przedłużaniu istnienia gatunku (długości i jakości życia), tak działalność artystyczna, również w aspektach opisanych przez Duttona, nie powinna być postrzegana z innej perspektywy. Nie sposób przeczyć statystyce. Jednak będący w mniejszości wielbiciele hermetycznego suprematyzmu czy transgresyjnego dadaizmu, osobniki poszukujące mniej oczywistych i bardziej niebanalnych wrażeń, za cenę pewnego intelektualnego wysiłku i emocjonalnego ryzyka zyskuja prawdopodobnie szerszą perspektywę na rzeczywistość i głębsze rozpoznanie stanów mentalnych człowieka. Wybierajacc wzorem romantycznych ,wichrzycieli” zamiast trawnika z oczkiem wodnym i płową zwierzyną skalistą pustynię, bezkres morza i otchłań kosmosu, poszerzaja swój zasób doświadczeń i zdolność podejmowania decyzji. W tym sensie 
definicja „sztuki” musi wadzić się z konformizmem większości jej „domyślnych” odbiorców. Badając powszechniki, Dutton dochodzi do wniosków właściwie przewidywalnych: realizując cele z niższych poziomów piramidy Maslowa, posługujemy się w pewnym zakresie narzędziami z górnych jej pięter. Dla zapewnienia pokarmu i partnera sięgamy po estetyczne „,sztuczki”. Jeśli jednak przyjrzeć się użyteczności pozornie wysublimowanych, transcendentnych potrzeb, którymi kierują się osoby porzucające obszary zasobne w pożywienie i partnerów, ich adaptacyjna użyteczność bardzo przypomina nieco efekt naukowego eksperymentu: zamiast korzyści doraźnych zyski potencjalne.

Po co się straszyć, snuć fantastyczne opowieści, wykonywać myślowe eksperymenty? Po co wizualizować odległe i niedostępne przestrzenie czy projektować geometryczne kompozycje? Przekonując, że instynkt „sztuki” ma podłoże adaptacyjne, Dutton nie doszacowuje jej aktualnego potencjału praktycznego, zwłaszcza gdy nie realizuje się on przez ukojenie i przyjemność. Cukier i tłuszcz, niegdyś rzadkie i niezbędne do przeżycia, dziś pospolite, szkodliwe i znieczulające, to jego ulubiony przykład zmysłowych reliktów plejstoceńskiej adaptacji. Wydaje się, że, przyjmujacc taką optykę, Dutton redukuje swoje ambicje z wyjaśnienia ewolucyjnych podstaw estetyki do skatalogowania zmysłowych aspektów instynktów adaptacyjnych: zamiast zajmować się ,sztuką, skupia się na użyteczności jej wybranych środków, w zawoalowany sposób włączając się w spór wielbicieli klasycyzmu („trzeźwi darwiniści”) i zwolenników awangardy („modne bzdury”). Paradoksalnie, teoria Duttona, będąc krokiem w kierunku utylitaryzacji sztuki, swoistym echem zooterapii, arteterapii i traktowania zjawiska $\mathrm{w}$ kategoriach dobrostanu psychosomatycznego jednostki, nawiązuje do artystycznych „ambicji” socrealizmu. Ten sam akademicki reżim i ta sama społeczna użyteczność. Otwarcie niekiedy konserwatywne poglądy Dutton moderuje hołdem dla gestu Duchampa, po drodze jednak teorię o dużym potencjale poznawczym - której zasługą mogłaby być redefinicja relacji „natury" z kulturą, a humanistyki z naukami przyrodniczymi w duchu „trzeciej kultury" — wikła w konserwatywną rekonkwistę spod znaku Donalda Kuspita. Aktualnie praktyka artystyczna czuje się lepiej po drugiej stronie barykady: nie tam, gdzie potiomkinowskie dekoracje łata się w nieskończoność, lecz tam, gdzie spod poszewki dobrze ugruntowanych paradygmatów prześwitują oznaki erozji. W sztuce ważniejsze jest dziś nie to, co konserwuje zastane normy, ale to, co w obliczu kryzysu bada potencjał rozwiązań alternatywnych. Teoria Duttona mogłaby znacznie zyskać, gdyby uwzględnić w rozważaniach nie tylko Darwina, ale też wracające dziś zwłaszcza w genetyce koncepcje Lamarcka, a obok pożytków z adaptacyjnego egoizmu rozpatrzeć korzyści płynące z międzygatunkowej współpracy.

\section{III}

W jednym z wywiadów dotyczących wystawy Wiek pótcienia jej kurator Sebastian Cichocki przyszłość człowieka lokuje w iście plejstoceńskiej scenerii: „Do końca stulecia przetrwa bardzo mała część ludzkości, zorganizowana w nieliczne grupy koczujące i żyjące blisko natury tam, gdzie będzie się dało żyć. My- 
ślę, że pewną rolę do odegrania wciąż będzie miała sztuka. Będzie przypominać praktyki z pogranicza sztuki konceptualnej i rolnictwa, bardzo bliskie życia, niemal nieodróżnialne od nieartystycznego tła"9. Współbrzmienie tej wizji z refleksją posthumanistyczną wydaje się dla dzisiejszej sztuki symptomatyczne, nie powinno jednak przesłaniać nie mniej ciekawego rezonansu z teoriac Duttona oraz nowym materializmem i Object Oriented Ontology. Być może zgodnie z zapowiedzią Sebastiana Cichockiego postsztuka zredukowana zostanie na powrót do organizacji przestrzeni w celu jak najlepszego skorelowania struktury otoczenia z jakością egzystencji, ewentualnie do optymalizacji wizerunku w celu maksymalnego zwiększenia biologicznej atrakcyjności. „Naturalistyczna” estetyka ewolucyjna wydaje się narzędziem bezpośrednio przystającym do wizji Cichockiego, warto jednak na naturę spojrzeć również oczami Timothy'ego Mortona, dla którego działania artystyczne okazują się najlepszym przygotowaniem do obcowania z ,hiperobiektami”. W jego perspektywie natura odzyskuje romantyczną aurę wzniosłości, osobliwości i niepospolitości, obecną głównie w nurtach, które Dutton uznałby za anomalie: manieryzmie, surrealizmie i bio-arcie. Wprawdzie opanowaliśmy już zamorskie krainy i alpejskie przełęcze, jednak w epoce internetu rzeczy i kryzysu klimatycznego rzeczywistość odzyskała całą swą tajemniczą, numinotyczną aurę. Wyróżniając w estetyce dwa, rozbieżne w zasadzie, imperatywy — przyjemność i satysfakcję z oglądania rzeczy wizualnie uporządkowanych lub pozytywnie konotowanych oraz coś wręcz przeciwnego: ciekawość i wzburzenie - akcentowałbym raczej adaptacyjny potencjał zaciekawienia rzeczami, które są niejednoznaczne, nie pasują do żadnego ze zmagazynowanych w naszym umyśle modeli. Wydaje się, że teoria Duttona, przeceniając pierwsze, nie doszacowuje drugich. Nie bierze pod uwagę tych wszystkich, którzy tworzą nie tylko „w służbie” Apollina (budowanie przyjaznego środowiska), ale i Dionizosa, przygotowując nas na nieoczekiwane w nim zmiany ${ }^{10}$. Towarzyszacc niejako badaniom psychologii postaci spod znaku Arnheima, psychologii poznawczej i neuronauk analizujących doświadczenie estetyczne z perspektywy specyficznych kompetencji percepcyjnych (jako manifestację sprawności w przetwarzaniu i sugestywnej prezentacji informacji), estetyka ewolucyjna może stanowić bezcenne wsparcie nie tylko $\mathrm{w}$ teorii sztuki, ale też $\mathrm{w}$ badaniach nad sztuczną inteligencją. Jeśli tylko uwzględnić w propozycji Duttona aktualny, jakże inny od sielskich widoków Komara i Melamida obraz natury, znajdujący silne odbicie w realizacjach sci-artu, bio-artu i net-artu, asymilujących narzędzia, media i technologie nauki, perspektywa ewolucyjna zyskuje zarysowaną w tytule książki Duttona powagę. Sztuka staje się wtedy mechanizmem pozwalającym rozpoznawać i komunikować niedowartościowane zagrożenia, skłaniającym do rozważenia alternatywnych perspektyw i scenariuszy. W tym sensie spór o genezę sztuki, próba wykluczenia jej natywnej (adaptacyjnej) bądź konstruktywnej (spekulatywnej i kulturowej) natury, staje się drugoplanowy. Sztuka nie jest wyłącznie ,konstruktem społecznym" ani uniwersalną, międzykulturową cechą ewolucyjną, ukształto-

9 Przytrzymywanie w żałobie. Rozmowa z Sebastianem Cichockim i Jagna Lewandowska, www.dwutygodnik.com (dostęp: 15.01.2021).

${ }^{10}$ F. Nietzsche, Narodziny tragedii, tłum. B. Baran, Warszawa 2009.

Studia Philosophica Wratislaviensia vol. XVI, fasc. 1, 2021 
waną w zgodzie z zasadami doboru naturalnego i płciowego. Jest po części i jednym, i drugim, przez co rozróżnienie na mechanizmy adaptacyjne i ich kulturowe „produkty uboczne” traci kluczowe znaczenie. Trudno dowieść fundamentalnej sprzeczności instynktownych potrzeb estetycznych z celami, jakie na płaszczyźnie społecznej realizuja programowane kulturowo instytucje finansujące i popularyzujące sztukę. Owe instytucje mogą być niejako kolejnym etapem w „ewolucji”" narzędzi, jakimi indywidualne instynkty estetyczne manifestują swą cywilizacyjną użyteczność. Ujawniając swoje funkcje, sztuka zyskuje wraz z nimi stosowne struktury instytucjonalne. Na poziomie indywidualnym odzwierciedlają one preferencje estetyczne, będące pochodną percepcyjnych instynktów i kulturowych konwencji. Na poziomie społecznym ich programy stają się wypadkową przewidywalnej do pewnego stopnia dynamiki cywilizacyjnej (progresji naukowej i technologicznej) oraz czegoś zgoła nieprzewidywalnego i akcydentalnego. Ów trzeci, obok potrzeb indywidualnych i społecznych programów, czynnik, znacząco korygujący kierunki poszukiwań artystycznych, można lokować właśnie w wywodzącym się z ontologii zorientowanej na przedmiot hiperobiekcie, niewidocznej, niekontrolowanej, lecz wszechobecnej strukturze, która cyklicznie definiuje „osobliwość” danej epoki, wpływając na kierunek poszukiwań artystów ${ }^{11}$.

Aktualna sytuacja wydaje się sprzyjać kolejnemu skojarzeniu praktyk o charakterze artystycznym z poznawczymi. Sama sztuka pozostaje nawet w swej definicji, podobnie jak nauka, wynalazkiem inteligencji, narzędziem proporcjonalnym do nadwyżki zasobów, jakimi dysponuje dana społeczność, pojawiającym się wraz z uzyskaniem określonego potencjału przestrzennego, surowcowego i informacyjnego. Kiedy Denis Dutton twierdzi, że tak jak intuicyjne rozpoznanie stanu zdrowia nie wymaga fachowej wiedzy medycznej, tak rozumna dyskusja o kategoriach estetycznych nie jest spętana kulturowymi kodami, wydaje się odnosić do bardzo ograniczonej sfery praktyk estetycznych. Nie ulega wątpliwości, że są wśród nich zarówno powszechne, ahistoryczne i globalne, jak i specyficzne, ograniczone przestrzennie i periodycznie ramą pewnej konwencji. Nasze autodiagnostyczne intuicje obarczone są nie tylko mimowolną ignorancją, lecz także niepełną świadomością subtelnych relacji łączących normę z patologią. Być może należałoby nie tyle szukać estetycznych powszechników, ile analizować dynamikę wyróżników. Badać nie cechy formalne zjawisk artystycznych, lecz zasady negocjowania ich definicji, proces „teoretycznego" komplikowania, abstrahowania i sublimowania praktyk estetycznych w perspektywie mechanizmów making special (Dissanayake) ${ }^{12}$. Niektóre formy estetycznego wyróżniania (określonych osób, przedmiotów lub zachowań) są powszechne dla wielu kultur. Trudno jednak wskazać w cywilizacjach innych niż zachodnia praktykę konceptualnej ,sakralizacji” przedmiotów utylitarnie pospolitych, co wydaje się charakterystyczne dla intelektualnego projektu, którego symbolem stała się „zdemobilizowana” toaleta, urynał domagający się „bezinteresownej” kontemplacji. Możliwe jednak, że i w tym geście kryła się pewna przystosowawcza intencja, brawurowym szturmem na akademickie tabu zwracająca uwage prawdzi-

11 T. Morton, Lepkość, tłum. A. Barcz, „Teksty Drugie” 2 (2018), s. 284-295.

12 E. Dissanayake, Homo Aestheticus. Where Art Comes From and Why, New York 1992. 
wych koneserów, a przez to wzmacniajacca „awangardowy” potencjał autora. Gest Duchampa, choć ryzykowny, przyniósł mu przecież sławę, która nie może równać się z doraźną popularnością większości ówczesnych twórców działających w paradygmacie ,siatkówkowym”.

Poszerzajac tradycyjne „pole sztuki”, Duchamp uposażył ją zarazem w nowe, rozległe zdolności ,koalicyjne”. Uwaga, z jaką świat artystyczny przyjmuje najnowsze doniesienia naukowe, potwierdza stale rosnącą atrakcyjność estetyczną badań i teorii poznawczych. Pozwalają one poszerzać sztukę o obszary pozostające do tej pory poza możliwością wizualnej reprezentacji. Niekiedy obserwować można symptomy wzajemności, wskazujące na potencjalne zainteresowanie intuicyjną i otwarcie eksperymentalną formuła praktyki artystycznej w zobligowanych ścisłą metodologia środowiskach naukowych. Spontaniczne badanie zależności między zjawiskami za pomocą sztuki w dalszej kolejności może prowadzić do bardziej szczegółowych i systematycznych badań uwarunkowanych już metodologią naukową. Zapotrzebowanie na wzajemną współpracę potęguje też zaawansowanie aktualnych badań i stopień komplikacji wyników. Jeśli obawy o utratę autonomii tak ,zadłużonej” w nauce sztuki uznamy za podobnie zasadne jak lęk o status nauki, która w toku zachodzących zmian może stać się narzędziem techniki, zautomatyzowanym przez zaawansowaną AI i służącym optymalizacji środowiska i warunków maksymalnie sprzyjających trwałości inteligencji biologicznej, badania Duttona nabierają dodatkowych sensów. Zarzucana mu „naturalizacja estetyki, czyli potraktowanie sztuki jako działalności naturalnej i ujmowanie jej przy pomocy pojęć z psychologii ewolucyjnej, operujaccej danymi empirycznymi""13 nie odczarowuje, jak sądzę, praktyki artystycznej, a raczej ,zaczarowuje” procesy fizjologiczne. Poszerzajac instytucjonalną teorię kultury o naturalistyczny aspekt, estetyka ewolucyjna, w posthumanistycznym kontekście dark ecology ${ }^{14}$, może stanowić element swoistej rewaloryzacji niezwykłości natury, w nurtach bio-art i sci-art eksplorowanej nie jako wzorzec wizualny, ale bezpośrednie narzędzie i surowiec sztuki. W siatce relacji pomiędzy zjawiskami uznawanymi dotychczas za wyłącznie kulturowe a tymi, które zachodzą na poziomie adaptacyjnym, wciąż pozostaje sporo do uporządkowania. Z perspektywy praktyki artystycznej teorię Duttona wydaje się obciążać nieprecyzyjna definicja sztuki, akcentująca pojęcia klasyczne, a pomijająca dorobek modernizmu, niedostrzegająca w niej narzędzia podnoszącego kompetencje poznawcze. Sztuka nie sprowadza się do uśrednionej preferencji, nie polega na sumiennym wymieszaniu statystycznie ustalonych upodobań wizualnych czy akustycznych (jak w eksperymencie Komara i Melamida), a być może wręcz przeciwnie: na niskiej entropii sensualnej, narracyjnej i wyrazowej. Jedną z najsłabszych stron teorii Duttona jest więc to, że nie znosi ona asymetrii pomiędzy tym, co przez sztukę rozumieją respondenci Komara i Melamida, a tym, jak jest ona definiowana i postrzegana przez specjalistów pracujacych na styku sztuki i społeczeństwa. Adresując swoja publikację do tych, którzy pragnęliby zrzu-

13 E. Chudoba, Ewolucjonizmy w estetyce $i$ ich konsekwencje, „Zeszyty Naukowe Towarzystwa Doktorantów UJ, Nauki Humanistyczne" 8 (2014), s. 81.

14 T. Morton, Dark Ecology, New York 2016. 
cić „,jarzmo" instytucjonalnego ucisku i uniknąć stępienia naturalnych instynktów ideologicznymi konstruktami, Dutton podważa zarówno skuteczność, jak i prawomocność projektów zmierzających do zmiany paradygmatu. Poszukując usprawiedliwienia obowiązującego porządku w mechanizmach „naturalnych”, sięga po preferencje większości. Nasuwa się pytanie: gdyby adaptacyjna użyteczność piękna była tak nieodparta, czy zamiast wyizolowanymi „ostojami” (muzeami i galeriami) nie powinniśmy dysponować całymi farmami i wytwórniami piękna? Jeśli ,instynkt sztuki" jest tak powszechny, skąd powszechna brzydota naszych siedlisk?

\section{Bibliografia}

Becker E., Zaprzeczanie śmierci, tłum. A. Trąbka, Kraków 2015.

Chudoba E., Ewolucjonizmy w estetyce $i$ ich konsekwencje, „Zeszyty Naukowe Towarzystwa Doktorantów UJ, Nauki Humanistyczne" 8 (1/2014), s. 69-88.

Dutton D., Instynkt sztuki. Piękno, zachwyt $i$ ewolucja człowieka, tłum. J. Luty Kraków 2020.

Dissanayake E., Homo Aestheticus. Where Art Comes From and Why, New York 1992.

Luty J., Estetyka ewolucyjna: sztuka jako adaptacja w ujęciu międzykulturowym, „Estetyka i Krytyka" 21 (2011), s. 101-114.

Morton T., Dark Ecology, New York 2016.

Morton T., Lepkość, tłum. A. Barcz, „Teksty Drugie” 2 (2018), s. 284-295.

Nietzsche F., Narodziny tragedii, tłum. B. Baran, Warszawa 2009.

Netografia

Przytrzymywanie w żałobie. Rozmowa z Sebastianem Cichockim i Jagna Lewandowska, www.dwutygodnik.com (dostęp: 15.01.2021).

Studia Philosophica Wratislaviensia vol. XVI, fasc. 1, 2021

(C) for this edition by CNS 